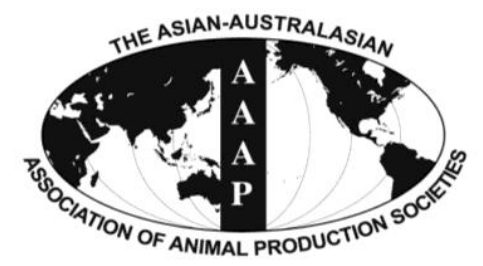

Asian-Aust. J. Anim. Sci.

Vol. 25, No. $3: 369$ - 374

March 2012

www.ajas.info

http://dx.doi.org/10.5713/ajas.2011.11089

\title{
Effects of Dietary Protein and Lipid Levels on Growth and Body Composition of Juvenile Far Eastern Catfish Silurus asotus
}

\author{
Kyoung-Duck Kim*, Sang Gu Lim ${ }^{1}$, Yong Jin Kang ${ }^{1}$, Kang-Woong Kim and Maeng Hyun Son \\ Aquafeed Research Center, National Fisheries Research and Development Institute, Pohang 791-923, Korea
}

\begin{abstract}
A $3 \times 2$ factorial experiment was conducted to determine the effects of dietary protein and lipid levels on the growth and body composition of juvenile far eastern catfish. Six diets were formulated to contain three levels of protein $(20 \%, 30 \%$ and $40 \%)$ and two levels of lipid (9\% and 17\%). Triplicate groups of fish (initial body weight of $7.6 \mathrm{~g}$ ) were hand-fed to apparent satiation for 66 days. Final mean weight was improved with increasing dietary protein and lipid levels, and the highest final mean weight was observed in fish fed the 40/17 (\% protein/\% lipid) diet. No significant difference was observed in final mean weight for fish fed between 30/17 diet and 40/9 diet. Feed efficiency of fish fed the diets containing over 30\% protein levels with $9 \%$ and $17 \%$ lipid levels were significantly higher than those of fish fed the $20 \%$ protein levels. Feed efficiency of fish fed the 30/17 diet was not significantly different from that of fish fed the 40/9 diet or 40/17 diet. Feed efficiency and protein efficiency ratio of fish fed the $20 \%$ protein diets with $17 \%$ lipid level were significantly higher than those of fish fed $9 \%$ lipid diet. Daily feed intake of fish tended to decrease with increasing dietary protein and lipid levels. Moisture content of whole body in fish fed the $9 \%$ lipid diets was significantly higher than that of fish fed the $17 \%$ lipid diets at the same protein level, but the opposite trends were found for crude lipid content. Significant effects of dietary lipid were observed for most fatty acids, according to their relative values in the diets. The results of this study suggest that the protein requirement for maximum growth of juvenile far eastern catfish may be higher than $40 \%$, and an increase of dietary lipid level from $9 \%$ to $17 \%$ can improve growth and feed utilization. (Key Words : Dietary Protein and Lipid, Far Eastern Catfish, Growth, Body Composition)
\end{abstract}

\section{INTRODUCTION}

Nutrient and energy sources in feed are needed for the growth and maintenance of fish. Fish are known to utilize protein preferentially to lipid or carbohydrate as an energy source (Walton and Cowey, 1982). Dietary protein is the most important factor affecting growth performance of fish and feed cost (Lovell, 1989). Therefore, it is important from a nutritional and economical point of view to improve protein utilization for tissue synthesis rather than for energy use.

Dietary lipids play important roles as a source of energy and essential fatty acids necessary for fish growth and development. Increasing the energy density of diets has been suggested as a strategy to spare protein and limit ammonia production for several fish species including red drum, Sciaenops ocellatus (McGoogan and Gatlin, 1999). A

\footnotetext{
* Corresponding Author : Kyoung-Duck Kim. Tel : +82-54-2325433, Fax : +82-54-232-5436, E-mail : kdkim@nfrdi.go.kr

${ }^{1}$ Inland Aquaculture Research Center, National Fisheries Research \& Development Institute, Jinhae 645-806, Korea.

Submitted Apr. 4, 2011; Accepted Jul. 19, 2011; Revised Jan. 2, 2012
}

supplementation of lipid rather than carbohydrate as a nonprotein energy source is generally more effective for increasing dietary energy level because lipid is an energydense nutrient that is readily metabolized by fish, especially by carnivorous fish (NRC, 1993).

Far eastern catfish is one of the most important commercial freshwater fish species, because this species has high consumer demand in Korea. This species is distributed in Korea, Japan, China and Taiwan (Chyoung, 1996). Aquaculture production of far eastern catfish has steadily increased during the last decade, and its production in 2010 reached 4,194 metric tons, which is second to eel $(7,902$ metric tons) among freshwater fish aquaculture in Korea (Statistics Korea, 2010).

Recently, nutritional studies evaluating availability of dietary lipid source and substitution of fish meal with soybean meal for growth in this species have been performed (Kim et al., 2009; 2010). However, information on growth performance of dietary protein and lipid levels is limited to date in this species. Therefore, this study was conducted to investigate the effects of dietary protein and lipid levels on the growth and body composition of juvenile 
far eastern catfish.

\section{MATERIALS AND METHODS}

\section{Design of the experimental diets and feeding trial}

A $3 \times 2$ factorial design with three replicates per dietary treatment was used in this study. Six experimental diets were formulated to contain three levels of protein $(20 \%$, $30 \%$ and $40 \%$ ) and two levels of lipid (9\% and 17\%). Gross energy levels of the diets were calculated based on 4, 9 and $4 \mathrm{kcal} / \mathrm{g}$ diets for protein, lipid and nitrogen-free extract, respectively (Garling and Wilson, 1976). Ingredients and nutrient contents of the experimental diets are presented in Table 1. To determine the effects of the three protein levels and two lipid levels, the amounts of fish meal, squid liver oil and soybean oil in the experimental diets were adjusted at the expense of dextrin and cellulose. Diets were prepared with a laboratory pellet machine after 35 to $40 \mathrm{~g}$ water was mixed with $100 \mathrm{~g}$ mixture of ingredients, and dried over night at room temperature. The experimental diets were stored in freezer at $-24^{\circ} \mathrm{C}$ until use.

\section{Fish and rearing conditions}

Juvenile far eastern catfish (Silurus asotus) were obtained from a local fish farm (Jinhae, Korea). They were acclimated to laboratory conditions for 2 weeks. Experimental fish (initial body weight $7.6 \pm 0.5 \mathrm{~g}$ ) were randomly distributed into each of eighteen $1,000 \mathrm{~L}$ cylindrical plastic tanks with 60 fish to each tank in semirecirculation system. Partial sedimentation and biofitration was used to maintain stable conditions. Fish were hand-fed to apparent satiation twice a day (0900 and 1700 h, 6 days a week) for 66 days. Freshwater was supplied at a flow rate of $10 \mathrm{~L} / \mathrm{min}$ in each tank. Mean water temperature and dissolved oxygen, based on weekly measurements, over the experimental periods were $25 \pm 1.7^{\circ} \mathrm{C}$ and $6.9 \pm 0.7 \mathrm{mg} / \mathrm{L}$, respectively. Photoperiod was left at natural condition during the feeding trial. All fish in each tank were weighed collectively at the beginning and end of feeding trial being fasted for $48 \mathrm{~h}$. Records were kept of daily feed consumption, mortalities and feeding behavior.

\section{Sample collections and chemical analysis}

At the end of the feeding trial, five fish in each tank were collected and stored in a freezer at $-70^{\circ} \mathrm{C}$ for chemical analysis. Crude protein was determined by Kjeldahl method using Auto Kjeldahl System (Gerhardt VAP50OT/TT125, KG, Germany). Crude lipid was determined by ether extraction using Soxhlet extractor (Velp SER 148, Usmate, Italy). Moisture was determined by oven drying at $135^{\circ} \mathrm{C}$

Table 1. Ingredients and nutrient contents of the experimental diets

\begin{tabular}{|c|c|c|c|c|c|c|}
\hline & \multicolumn{6}{|c|}{ Diets (\% protein/\% lipid) } \\
\hline & $20 / 9$ & $20 / 17$ & $30 / 9$ & $30 / 17$ & $40 / 9$ & $40 / 17$ \\
\hline \multicolumn{7}{|l|}{ Ingredients (\%) } \\
\hline Brown fish meal ${ }^{1}$ & 27 & 27 & 40.5 & 40.5 & 54 & 54 \\
\hline Dextrin & 42 & 34 & 32 & 24 & 22 & 14 \\
\hline$\alpha-S t a r c h$ & 15 & 15 & 15 & 15 & 15 & 15 \\
\hline Squid liver oil $^{2}$ & 3.8 & 3.8 & 2.4 & 2.4 & 1 & 1 \\
\hline Soybean oil & 3.5 & 11.5 & 3.5 & 11.5 & 3.5 & 11.5 \\
\hline$\alpha$-Cellulose & 4.2 & 4.2 & 2.1 & 2.1 & & \\
\hline Vitamin premix ${ }^{3}$ & 2 & 2 & 2 & 2 & 2 & 2 \\
\hline Mineral premix ${ }^{3}$ & 2 & 2 & 2 & 2 & 2 & 2 \\
\hline Choline chloride & 0.5 & 0.5 & 0.5 & 0.5 & 0.5 & 0.5 \\
\hline \multicolumn{7}{|l|}{ Nutrient contents (dry matter basis) } \\
\hline Crude protein $(\%)$ & 20.0 & 20.4 & 29.7 & 30.3 & 39.2 & 39.9 \\
\hline Crude lipid (\%) & 7.7 & 14.9 & 9.0 & 16.6 & 9.5 & 17.6 \\
\hline $\operatorname{Ash}(\%)$ & 4.7 & 4.9 & 6.7 & 6.8 & 8.6 & 8.6 \\
\hline Crude fiber $(\%)$ & 4.6 & 4.7 & 3.0 & 3.2 & 2.0 & 2.5 \\
\hline $\operatorname{NFE}(\%)^{4}$ & 63.1 & 55.0 & 51.5 & 43.1 & 40.7 & 31.3 \\
\hline Gross energy (kcal/g diet) & 4.01 & 4.36 & 4.06 & 4.43 & 4.05 & 4.43 \\
\hline Protein to energy ratio (mg/kcal) & 50 & 47 & 73 & 68 & 97 & 90 \\
\hline n-3 HUFA ${ }^{5}$ & 1.0 & 1.3 & 1.2 & 1.3 & 1.4 & 1.5 \\
\hline
\end{tabular}

${ }^{1}$ Imported from Chile. ${ }^{2}$ Provided by E-wha Oil and Fat Industry Corporation, Busan, South Korea.

${ }^{3}$ Same as Lee et al. (2003). ${ }^{4}$ Nitrogen-free extract calculated by the difference $(=100$-crude protein-crude lipid-ash-crude fiber).

${ }^{5}$ Highly unsaturated fatty acids $(\mathrm{C} \geq 20)$, calculated (dietary total lipid \%×area \%×0.892). (Yoshimatsu et al., 1997). 
Table 2. Major fatty acids composition (\% of total fatty acids) of the experimental diets

\begin{tabular}{lrrrrrr}
\hline & \multicolumn{6}{c}{ Diets (\% protein/\% lipid) } \\
\cline { 2 - 7 } & $20 / 9$ & $20 / 17$ & $30 / 9$ & $30 / 17$ & $40 / 9$ & $40 / 17$ \\
\hline C14:0 & 2.9 & 1.8 & 2.8 & 1.5 & 2.7 & 1.4 \\
C16:0 & 14.3 & 13.7 & 14.9 & 13.7 & 16.0 & 13.8 \\
C16:1n-7 & 5.1 & 3.5 & 4.7 & 2.6 & 3.8 & 2.0 \\
C18:0 & 3.2 & 2.1 & 3.8 & 5.9 & 5.2 & 2.8 \\
C18:1n-9 & 25.4 & 27.1 & 24.4 & 24.5 & 23.2 & 28.0 \\
C18:2n-6 & 24.0 & 33.6 & 24.3 & 35.7 & 23.2 & 36.4 \\
C18:3n-3 & 5.2 & 3.6 & 4.0 & 2.7 & 2.3 & 1.8 \\
C20:2n-6 & 1.5 & 0.9 & 1.2 & 0.8 & 1.0 & 0.6 \\
C20:4n-6 & 0.4 & 0.3 & 0.5 & 0.3 & 0.6 & 0.4 \\
C20:5n-3 & 6.5 & 4.4 & 6.6 & 3.7 & 6.6 & 3.4 \\
C22:5n-3 & 0.8 & 0.6 & 1.0 & 0.6 & 1.3 & 0.7 \\
C22:6n-3 & 6.2 & 4.1 & 6.4 & 3.8 & 8.0 & 4.6 \\
n-3HUFA & 14.3 & 10.0 & 14.8 & 8.7 & 16.6 & 9.7 \\
\hline
\end{tabular}

${ }^{1}$ Highly unsaturated fatty acids $(\mathrm{C} \geq 20)$.

for $2 \mathrm{~h}$. Ash was determined by muffle furnace at $550^{\circ} \mathrm{C}$ for $6 \mathrm{~h}$. Crude fiber was determined by an automatic analyzer (Fibertec, Tecator, Hoganas, Sweden). Nitrogen free extract was calculated by difference. Lipid for fatty acid analysis was extracted by mixture of chloroform and methanol according to the method of Folch et al. (1957). The fatty acid composition was determined after methylation with $14 \% \mathrm{BF}_{3}$ methanol (Sigma, St Louis, MO, USA) by a gas chromatography (HP-6890N, Hewlett-Packard, Palo Alto, CA, USA) with a flame ionization detector, equipped with $\mathrm{SP}^{\mathrm{TM}}-2560$ capillary column $(100 \mathrm{~m} \times 0.25 \mathrm{~mm}$ i.d., film thickness $0.20 \mu \mathrm{m}$; Supelco, Bellefonte, PA, USA). Injector and detector temperatures were $260^{\circ} \mathrm{C}$. The column temperature was programmed from $140^{\circ} \mathrm{C}$ to $240^{\circ} \mathrm{C}$ at a rate of $4^{\circ} \mathrm{C} / \mathrm{min}$. Helium was used as the carrier gas. Fatty acids were identified by comparison with known standards.

\section{Statistical analysis}

The data were subjected to a two-way ANOVA to test the effects of the dietary protein and lipid levels on fish performance. If significant $(\mathrm{p}<0.05)$ differences were found in factors, Duncan's multiple range test (Duncan, 1955) was used to rank the means. All statistical analyses were carried out by using the SPSS program Version 11.5 (SPSS, Chicago, Illinois, USA).

\section{RESULTS}

\section{Growth performance}

Survival of juvenile far eastern catfish in response to diets containing 20 to $40 \%$ protein and 9 to $17 \%$ lipid for 66 day was over $88 \%$, and there were no significant difference among all groups (Table 3). Final mean weight, feed efficiency, protein efficiency ratio, daily feed intake and daily protein intake were significantly affected by both dietary protein and lipid levels $(\mathrm{p}<0.01)$. Final mean weight was improved with increasing dietary protein and lipid levels, and the highest final mean weight was observed in fish fed the 40/17 (\% protein/\% lipid) diet. No significant difference was observed in final mean weight for fish fed between 30/17 diet and 40/9 diet. Feed efficiency (FE) of fish fed the diets containing over $30 \%$ protein levels with $9 \%$ and $17 \%$ lipid levels were significantly higher than those of fish fed the $20 \%$ protein levels $(\mathrm{p}<0.05)$. FE of fish fed the 30/17 diet was not significantly different from that of fish fed the 40/9 diet or 40/17 diet. Protein efficiency ratio (PER) was significantly decreased with increasing dietary protein level $(\mathrm{p}<0.05)$. FE and PER of fish fed the $20 \%$ protein diet with $17 \%$ lipid level were significantly higher than those of fish fed $9 \%$ lipid diet $(\mathrm{p}<0.05)$. Daily

Table 3. Growth performance of juvenile far eastern catfish fed diets containing three protein and two lipid levels for 66 days

\begin{tabular}{|c|c|c|c|c|c|c|c|c|}
\hline $\begin{array}{l}\text { Protein } \\
(\%)\end{array}$ & $\begin{array}{l}\text { Lipid } \\
(\%)\end{array}$ & $\begin{array}{c}\text { Initial mean } \\
\text { weight (g/fish) }\end{array}$ & $\begin{array}{l}\text { Survival } \\
(\%)\end{array}$ & $\begin{array}{c}\text { Final mean } \\
\text { weight (g/fish) }\end{array}$ & $\begin{array}{l}\text { Feed efficiency } \\
(\%)^{1}\end{array}$ & $\begin{array}{l}\text { Protein } \\
\text { efficiency ratio }^{2}\end{array}$ & $\begin{array}{l}\text { Daily feed } \\
\text { intake }^{3}\end{array}$ & $\begin{array}{c}\text { Daily protein } \\
\text { intake }^{3}\end{array}$ \\
\hline 20 & 9 & $7.5 \pm 0.3^{\mathrm{ns}}$ & $93 \pm 1.1^{\mathrm{ns}}$ & $43 \pm 0.4^{\mathrm{a}}$ & $61 \pm 0.9^{\mathrm{a}}$ & $3.20 \pm 0.05^{\mathrm{c}}$ & $3.49 \pm 0.04^{\mathrm{d}}$ & $0.66 \pm 0.01^{b}$ \\
\hline 20 & 17 & $7.7 \pm 0.3$ & $94 \pm 1.5$ & $46 \pm 1.3^{b}$ & $71 \pm 1.5^{\mathrm{b}}$ & $3.55 \pm 0.07^{\mathrm{d}}$ & $3.08 \pm 0.02^{c}$ & $0.61 \pm 0.00^{\mathrm{a}}$ \\
\hline 30 & 9 & $7.4 \pm 0.4$ & $94 \pm 1.5$ & $59 \pm 1.1^{\mathrm{c}}$ & $78 \pm 0.2^{\mathrm{c}}$ & $2.71 \pm 0.01^{b}$ & $3.02 \pm 0.00^{\mathrm{bc}}$ & $0.87 \pm 0.00^{\mathrm{c}}$ \\
\hline 30 & 17 & $7.6 \pm 0.2$ & $94 \pm 1.5$ & $64 \pm 0.4^{\mathrm{d}}$ & $82 \pm 0.9^{\mathrm{cd}}$ & $2.78 \pm 0.03^{b}$ & $2.92 \pm 0.02^{\mathrm{b}}$ & $0.86 \pm 0.01^{\mathrm{c}}$ \\
\hline 40 & 9 & $7.5 \pm 0.4$ & $91 \pm 4.3$ & $65 \pm 0.7^{\mathrm{d}}$ & $84 \pm 1.7^{\mathrm{d}}$ & $2.20 \pm 0.05^{\mathrm{a}}$ & $2.95 \pm 0.05^{\mathrm{bc}}$ & $1.13 \pm 0.02^{\mathrm{e}}$ \\
\hline 40 & 17 & $7.7 \pm 0.2$ & $88 \pm 3.5$ & $78 \pm 0.7^{\mathrm{e}}$ & $87 \pm 3.1^{\mathrm{d}}$ & $2.25 \pm 0.08^{\mathrm{a}}$ & $2.76 \pm 0.08^{\mathrm{a}}$ & $1.06 \pm 0.03^{\mathrm{d}}$ \\
\hline \multicolumn{9}{|c|}{ Two-way ANOVA } \\
\hline \multicolumn{2}{|c|}{ Protein } & & $\mathrm{p}<0.2$ & $\mathrm{p}<0.01$ & $\mathrm{p}<0.01$ & $\mathrm{p}<0.01$ & $\mathrm{p}<0.01$ & $\mathrm{p}<0.01$ \\
\hline \multicolumn{2}{|l|}{ Lipid } & & $\mathrm{p}<0.8$ & $\mathrm{p}<0.01$ & $\mathrm{p}<0.01$ & $\mathrm{p}<0.01$ & $\mathrm{p}<0.01$ & $\mathrm{p}<0.01$ \\
\hline \multicolumn{2}{|c|}{ Interaction } & & $\mathrm{p}<0.9$ & $\mathrm{p}<0.01$ & $\mathrm{p}<0.1$ & $\mathrm{p}<0.05$ & $\mathrm{p}<0.05$ & $\mathrm{p}<0.2$ \\
\hline
\end{tabular}

Values (mean \pm SE of three replications) in the same column not sharing a common superscript letter are significantly different ( $<<0.05$ ).

${ }^{1}$ Fish wet weight gain $\times 100 /$ feed intake (dry matter). ${ }^{2}$ Fish wet weight gain/protein intake.

${ }^{3}$ Feed intake (or protein $) \times 100 /\left((\right.$ initial fish wt.+final fish wt.+dead fish wt. $) \times$ days fed/2). ${ }^{\text {ns }}$ Not significant $(\mathrm{p}>0.05)$. 
Table 4. Proximate compositions of whole body in juvenile far eastern catfish fed diets containing three protein and two lipid levels for 66 days

\begin{tabular}{lclccc}
\hline Protein (\%) & Lipid (\%) & Moisture (\%) & Crude protein (\%) & Crude lipid (\%) & Ash (\%) \\
\hline 20 & 9 & $72.7 \pm 0.08^{\mathrm{b}}$ & $14.6 \pm 0.57^{\mathrm{ns}}$ & $8.2 \pm 0.30^{\mathrm{ab}}$ & $2.5 \pm 0.06^{\mathrm{ns}}$ \\
20 & 17 & $70.8 \pm 0.38^{\mathrm{a}}$ & $14.0 \pm 0.11$ & $11.4 \pm 1.11^{\mathrm{b}}$ & $2.2 \pm 0.01$ \\
30 & 9 & $74.6 \pm 0.62^{\mathrm{c}}$ & $14.6 \pm 0.44$ & $5.5 \pm 0.41^{\mathrm{a}}$ & $2.3 \pm 0.26$ \\
30 & 17 & $72.0 \pm 0.43^{\mathrm{ab}}$ & $14.4 \pm 0.09$ & $9.4 \pm 0.62^{\mathrm{b}}$ & $2.2 \pm 0.14$ \\
40 & 9 & $74.7 \pm 0.92^{\mathrm{c}}$ & $15.0 \pm 0.06$ & $6.1 \pm 0.92^{\mathrm{a}}$ & $2.3 \pm 0.05$ \\
40 & 17 & $71.3 \pm 0.53^{\mathrm{ab}}$ & $15.2 \pm 0.09$ & $10.0 \pm 1.70^{\mathrm{b}}$ & $2.3 \pm 0.11$ \\
Two-way ANOVA & & & & $\mathrm{p}<0.1$ & $\mathrm{p}<0.7$ \\
$\quad$ Protein & & $\mathrm{p}<0.05$ & $\mathrm{p}<0.1$ & $\mathrm{p}<0.01$ & $\mathrm{p}<0.3$ \\
$\quad$ Lipid & $\mathrm{p}<0.01$ & $\mathrm{p}<0.5$ & $\mathrm{p}<0.9$ & $\mathrm{p}<0.6$ \\
$\quad$ Interaction & $\mathrm{p}<0.5$ & $\mathrm{p}<0.5$ & & \\
\hline
\end{tabular}

Values (mean \pm SE of three replications) in the same column not sharing a common superscript letter are significantly different ( $<<0.05$ ).

${ }^{n s}$ Not significant $(\mathrm{p}>0.05)$.

feed intake of fish tended to decrease with increasing dietary protein and lipid levels. Daily protein intake of fish was significantly increased with increasing dietary protein level $(\mathrm{p}<0.05)$, and tended to decrease with increasing dietary lipid level. Significant interactions between protein and lipid levels were founded for final mean weight, PER and daily feed intake.

\section{Body composition}

Moisture content of whole body was significantly affected by dietary protein $(\mathrm{p}<0.05)$ and lipid $(\mathrm{p}<0.01)$ levels (Table 4). Crude lipid content of whole body was significantly affected by dietary lipid levels $(p<0.01)$.
Moisture content of whole body in fish fed the $9 \%$ lipid diets were significantly higher than that of fish fed the $17 \%$ lipid diets at the same protein level $(\mathrm{p}<0.05)$, but the opposite trends were found for crude lipid content. No significant differences were observed in crude protein and ash contents. Fatty acids composition of whole body in juvenile far eastern catfish fed the diets containing various protein and lipid levels are shown in Table 5. Significant effects of dietary lipid were observed for most fatty acids, according to their relative values in the diets. The fish fed the $9 \%$ the lipid diets showed the significantly higher contents of 14:0, 16:1n-7, 20:2n-6, 20:5n-3, 22:5n-3, $22: 6 n-3, n-3$ poly unsaturated fatty acids (PUFA) and n-3

Table 5. Major fatty acids composition (\% of total fatty acids) of whole body in juvenile far eastern catfish fed diets containing three protein and two lipid levels for 66 days

\begin{tabular}{|c|c|c|c|c|c|c|c|c|c|c|}
\hline \multirow{2}{*}{$\begin{array}{l}\text { Protein } \\
\text { Lipid }\end{array}$} & \multicolumn{2}{|c|}{20} & \multicolumn{2}{|c|}{30} & \multicolumn{2}{|c|}{40} & \multirow{2}{*}{$\begin{array}{c}\text { Pooled } \\
\text { SEM }\end{array}$} & \multicolumn{3}{|c|}{ Two-way ANOVA } \\
\hline & 9 & 17 & 9 & 17 & 9 & 17 & & Protein & Lipid & Interaction \\
\hline C14:0 & $2.5^{\mathrm{b}}$ & $1.8^{\mathrm{a}}$ & $2.5^{\mathrm{b}}$ & $1.6^{\mathrm{a}}$ & $2.5^{\mathrm{b}}$ & $1.6^{\mathrm{a}}$ & 0.10 & $\mathrm{p}<0.5$ & $\mathrm{p}<0.01$ & $\mathrm{p}<0.4$ \\
\hline C16:0 & $16.0^{\mathrm{a}}$ & $15.5^{\mathrm{a}}$ & $16.9^{\mathrm{a}}$ & $15.8^{\mathrm{a}}$ & $18.9^{\mathrm{b}}$ & $16.1^{\mathrm{a}}$ & 0.33 & $\mathrm{p}<0.01$ & $\mathrm{p}<0.01$ & $\mathrm{p}<0.1$ \\
\hline $\mathrm{C} 16: 1 \mathrm{n}-7$ & $5.9^{\mathrm{b}}$ & $4.2^{\mathrm{a}}$ & $6.4^{\mathrm{bc}}$ & $3.7^{\mathrm{a}}$ & $6.8^{\mathrm{c}}$ & $4.1^{\mathrm{a}}$ & 0.31 & $\mathrm{p}<0.3$ & $\mathrm{p}<0.01$ & $\mathrm{p}<0.1$ \\
\hline C18:0 & $7.7^{\mathrm{ns}}$ & 4.9 & 5.0 & 5.9 & 5.3 & 6.9 & 0.42 & $\mathrm{p}<0.7$ & $\mathrm{p}<0.9$ & $\mathrm{p}<0.1$ \\
\hline C18:1n-9 & $21.5^{\mathrm{ns}}$ & 24.9 & 25.4 & 24.3 & 26.0 & 24.5 & 0.51 & $\mathrm{p}<0.2$ & $\mathrm{p}<0.8$ & $\mathrm{p}<0.1$ \\
\hline C18:2n-6 & $20.2^{\mathrm{b}}$ & $28.3^{\mathrm{c}}$ & $18.8^{\mathrm{b}}$ & $29.8^{\mathrm{cd}}$ & $16.6^{\mathrm{a}}$ & $30.1^{\mathrm{d}}$ & 1.37 & $\mathrm{p}<0.2$ & $\mathrm{p}<0.01$ & $\mathrm{p}<0.01$ \\
\hline C18:3n-3 & $4.1^{\mathrm{d}}$ & $3.4^{\mathrm{c}}$ & $3.2^{\mathrm{c}}$ & $2.7^{\mathrm{b}}$ & $2.0^{\mathrm{a}}$ & $1.7^{\mathrm{a}}$ & 0.20 & $\mathrm{p}<0.01$ & $\mathrm{p}<0.01$ & $\mathrm{p}<0.5$ \\
\hline$C 20: 2 n-6$ & $3.9^{\mathrm{d}}$ & $2.7^{\mathrm{b}}$ & $3.6^{\mathrm{cd}}$ & $2.4^{\mathrm{b}}$ & $3.3^{\mathrm{c}}$ & $1.9^{\mathrm{a}}$ & 0.17 & $\mathrm{p}<0.01$ & $\mathrm{p}<0.01$ & $\mathrm{p}<0.8$ \\
\hline C20:4n-6 & $0.9^{\mathrm{ns}}$ & 0.9 & 0.8 & 0.9 & 0.8 & 0.8 & 0.02 & $\mathrm{p}<0.1$ & $\mathrm{p}<0.7$ & $\mathrm{p}<0.7$ \\
\hline C20:5n-3 & $5.3^{\mathrm{c}}$ & $3.2^{\mathrm{a}}$ & $4.8^{\mathrm{bc}}$ & $3.0^{\mathrm{a}}$ & $4.5^{\mathrm{b}}$ & $2.8^{\mathrm{a}}$ & 0.24 & $\mathrm{p}<0.05$ & $\mathrm{p}<0.01$ & $\mathrm{p}<0.6$ \\
\hline$C 22: 2 n-6$ & $1.5^{\mathrm{b}}$ & $1.2^{\mathrm{b}}$ & $1.5^{\mathrm{b}}$ & $1.0^{\mathrm{ab}}$ & $1.2^{\mathrm{b}}$ & $0.6^{\mathrm{a}}$ & 0.09 & $\mathrm{p}<0.05$ & $\mathrm{p}<0.01$ & $\mathrm{p}<0.7$ \\
\hline C22:5n-3 & $1.6^{\mathrm{b}}$ & $1.2^{\mathrm{a}}$ & $1.7^{\mathrm{bc}}$ & $1.1^{\mathrm{a}}$ & $1.9^{\mathrm{c}}$ & $1.1^{\mathrm{a}}$ & 0.07 & $\mathrm{p}<0.3$ & $\mathrm{p}<0.01$ & $\mathrm{p}<0.05$ \\
\hline$C 22: 6 n-3$ & $6.6^{\mathrm{b}}$ & $4.9^{\mathrm{a}}$ & $6.7^{\mathrm{bc}}$ & $4.8^{\mathrm{a}}$ & $7.5^{\mathrm{c}}$ & $4.9^{\mathrm{a}}$ & 0.28 & $\mathrm{p}<0.3$ & $\mathrm{p}<0.01$ & $\mathrm{p}<0.3$ \\
\hline$n-3$ PUFA $^{1}$ & $18.0^{\mathrm{d}}$ & $13.1^{\mathrm{b}}$ & $16.9^{\mathrm{cd}}$ & $12.0^{\mathrm{ab}}$ & $16.3^{\mathrm{c}}$ & $10.8^{\mathrm{a}}$ & 0.66 & $\mathrm{p}<0.01$ & $\mathrm{p}<0.01$ & $\mathrm{p}<0.8$ \\
\hline$n-6$ PUFA $^{1}$ & $27.3^{\mathrm{c}}$ & $34.1^{\mathrm{d}}$ & $25.8^{\mathrm{b}}$ & $35.3^{\mathrm{d}}$ & $22.9^{\mathrm{a}}$ & $34.6^{\mathrm{d}}$ & 1.18 & $\mathrm{p}<0.01$ & $\mathrm{p}<0.01$ & $\mathrm{p}<0.01$ \\
\hline$n-3$ HUFA $^{2}$ & $14.3^{\mathrm{b}}$ & $10.0^{\mathrm{a}}$ & $14.1^{\mathrm{b}}$ & $9.6^{\mathrm{a}}$ & $14.8^{\mathrm{b}}$ & $9.4^{\mathrm{a}}$ & 0.60 & $\mathrm{p}<0.8$ & $\mathrm{p}<0.01$ & $\mathrm{p}<0.6$ \\
\hline
\end{tabular}

Values (mean of three replications) in each row not sharing a common superscript are significantly different $(\mathrm{p}<0.05)$.

${ }^{1}$ Polyunsaturated fatty acids $(C \geq 18) .{ }^{2}$ Highly unsaturated fatty acid $(C \geq 20)$. ${ }^{\text {ns }}$ Not significant $(p>0.05)$. 
highly unsaturated fatty acids (HUFA) than those of fish fed the $17 \%$ lipid diets $(\mathrm{p}<0.05)$. However, 18:2n-6 and $\mathrm{n}-6$ PUFA contents of fish fed the $17 \%$ lipid diets were significantly higher than those of fish fed the $9 \%$ lipid diets at all protein levels $(\mathrm{p}<0.05)$.

\section{DISCUSSION}

Improved growth and feed efficiency with increasing dietary protein levels is well known in fish (NRC, 1993). In the present study, growth performance was increased from $20 \%$ to $40 \%$ protein levels at the same dietary lipid level. The result indicates that the protein requirement for maximum growth of juvenile far eastern catfish may be higher than $40 \%$. The dietary protein requirement for juvenile far eastern catfish determined in this study is comparable to protein requirements (42-44\%) estimated for bagrid catfish Pseudobagrus fulvidraco (Kim and Lee, 2005) and Malaysian freshwater catfish Mystus nemurus (Khan et al., 1993), but is higher compared with the dietary protein requirements of 32 to $36 \%$ reported for channel catfish Ictalurus punctatus (Garling and Wilson, 1976).

Growth rate of far eastern catfish fed the $17 \%$ lipid diets was significantly higher than that of fish fed the $9 \%$ lipid diets at all dietary protein levels, and improvement in weight gain, FE and PER of fish fed the 30/17 diet were compared with those of fish fed the 40/9 diet. These results indicate that increasing the dietary energy level by lipid will provide a more efficient utilization of dietary protein for the growth of fish. Improvement of fish performance at increasing dietary energy levels was observed in some other catfish species (Page and Andrews, 1973; Pei et al., 2004). Protein sparing effect by dietary lipid is well established (Cho and Kaushik, 1990). It is important to provide an adequate level and ratio of dietary protein and non-protein energy in order to reduce catabolism of protein for energy. The optimum protein to energy ratio in diet for maximum growth for several fish species such as rainbow trout, Salmo gairdneri and Hybrid bass, Moroni chrysops $\times$ M. saxitalis ranged from 81 to $112 \mathrm{mg} / \mathrm{kcal}$ (NRC, 1993). The maximum growth rate was obtained in fish fed the 40/17 diet in this study, corresponding to a protein to energy ratio of $90 \mathrm{mg} / \mathrm{kcal}$, which is similar to that $(88 \mathrm{mg} / \mathrm{kcal})$ for channel catfish fingerlings (Garling and Wilson, 1976).

Dietary protein and lipid levels could affect on PER of fish. The PER increased with decrease in dietary protein at the same lipid level in this study. Similar result of improved PER with decreasing dietary protein level was reported in other studies (Lee et al., 2002; Kim and Lee, 2005).

This study showed a lower daily feed intake for fish fed the $17 \%$ lipid diets than $9 \%$ lipid diets. Similar results of reduced feed consumption of fish fed a high-energy diet compared with a low-energy diet have been reported in other species of fish (Lee and Putnam, 1973; Page and Andrews, 1973; Lee et al., 2002). The high-energy diet caused a reduction in feed intake, probably because fish eat to satisfy their energy requirements. Daily feed intake was negatively correlated with dietary lipid level $(r=-0.64$, $\mathrm{p}<0.01)$ in this study.

The practice of increasing of dietary lipid levels should be carefully considered as it may affect carcass quality, flavor and storage characteristics, as a result of increased lipid deposition (Cowey, 1993; Hillestad and Johnsen, 1994). In this study, the lipid contents of fish were positively correlated with dietary lipid level. This is an agreement with other studies showing that lipid content of fish fed high energy diets is higher than that of fish fed low energy diets (Kim and Lee, 2005). Despite of increase of body lipid contents in the high lipid diets, considering the improvement of growth performance, high lipid diets seem to have more beneficial effects for fish performance compared to low lipid diets when proper protein is provided (Kim and Lee, 2005; Ahmad, 2008). Moreover, the decrease of feed and protein intakes in high lipid diets in this study appears to have an effect of reduction of ammonia production as described by McGoogan and Gatlin (1999).

The fatty acid composition of fish in this study well reflected the fatty acid composition of dietary lipid. Similar results had been founded in previous catfish study (Kim et al., 2010). Kim et al. (2010) reported that linseed oil or squid liver oil containing n-3 fatty acids are the proper dietary lipid sources for the growth of juvenile far eastern catfish. The importance of essential fatty acids, largely two types, linoleic acid and linolenic acid, for most of freshwater fish has been reported (NRC, 1993). Linolenic acid requirement of fresh water fish species ranged from $0.5 \%$ to $2 \%$ of the diet (NRC, 1993), and Satoh et al. (1989) reported that dietary essential fatty acids requirement for channel catfish is 1 to $2 \%$ linolenic acid or 0.5 to $0.75 \%$ n-3 HUFA such as 20:5n-3 and 22:6n-3. In this study, fish meal and squid liver oil contained considerable content of n-3 HUFA were used in experimental diets. Although information on requirement level of n-3 fatty acids for far eastern catfish is unknown, 1.0 to $1.5 \%$ n-3 HUFA in diets used in this study was above the requirement for n-3HUFA of channel catfish.

The results of this study suggest that the protein requirement for maximum growth of juvenile far eastern catfish may be higher than $40 \%$, and increase of dietary lipid level from $9 \%$ to $17 \%$ can improve growth and feed utilization.

\section{ACKNOWLEDGEMENTS}

This work was funded by a grant from the National 
Fisheries Research and Development Institute (RP-2011AQ-123).

\section{REFERENCES}

Ahmad, M. H. 2008. Response of African catfish, Clarias gariepinus, to different dietary protein and lipid levels in practical diets. J. World Aquac. Soc. 39:541-548.

Cho, C. Y. and S. J. Kaushik. 1990. Nutritional energetics in fish: energy and protein utilization in rainbow trout (Salmo gairdneri). World Rev. Nutr. Diet. 61:132-172.

Chyoung, M. K. 1996. The Fishes of Korea, 5th ED. Il Ji Co., Seoul.

Cowey, C. B. 1993. Some effects of nutrition and flesh quality of cultured fish. In: Fish Nutrition in Practice (Ed. S. J. Kaushik and P. Luquet), Proc. of the IV Int. Symp. on Fish Nutrition and Feeding, vol. 61, Les Colloques INRA, Paris, pp. 227-236.

De Silva, S. S., R. M. Gunasekera and K. F. Shim. 1991. Interactions of varying dietary protein and lipid levels in young red tilapia: evidence of protein sparing. Aquaculture 95: 305-318.

Duncan, D. B. 1955. Multiple-range and multiple $F$ tests. Biometrics 11:1-42.

Folch, J., M. Lees and G. H. Sloane-Stanley. 1957. A simple method for the isolation and purification of total lipids from animal tissues. J. Biol. Chem. 226:497-509.

Garling, D. L. and R. P. Wilson. 1976. Optimum dietary protein to energy ratios for channel catfish fingerlings, Ictalurus punctatus. J. Nutr. 106:1368-1375.

Hillestad, M. and F. T. Johnsen. 1994. High-energy/low-protein diets for Atlantic salmon: effects on growth, nutrient retention and slaughter quality. Aquaculture 124:109-116.

Khan, M. S., K. J. Ang, M. A. Ambak and C. R. Saad. 1993. Optimum dietary protein requirement of a Malaysian freshwater catfish, Mystus nemurus. Aquaculture 112:227-235.

Kim, L. O. and S. M. Lee. 2005. Effects of the dietary protein and lipid levels on growth and body composition of bagrid catfish, Pseudobagrus fulvidraco. Aquaculture 243:323-329.

Kim, K. D., S. G. Lim, J. A. Hwang, J. D. Kim and Y. J. Kang. 2009. Evaluation of soybean meal as a partial substitute for fish meal in diet and experimental practical diet for growth in the far eastern catfish (Silurus asotus). Korean J. Fish. Aquat. Sci. 42:349-353.
Kim, K. D., J. D. Kim, S. G. Lim, Y. J. Kang and M. H. Son. 2010. Effects of dietary lipid sources on the growth and body composition of the far eastern catfish, Silurus asotus. Kor. J. Fish. Aquat. Sci. 43:445-450.

Lee, S. M., D. J. Kim and S. H. Choi. 2002. Effects of dietary protein and lipid level on growth and body composition of juvenile ayu (Plecoglossus altivelis) reared in seawater. Aquac. Nutr. 8: 53-58.

Lee, D. J. and G. B. Putnam. 1973. The response of rainbow trout to varying protein/energy ratios in a test diet. J. Nutr. 103:916922.

Lee, S. M., K. D. Kim and S. P. Lall. 2003. Utilization of glucose, maltose, dextrin and cellulose by juvenile flounder (Paralichthys olivaceus). Aquaculture 221:427-438.

Lovell, R. T. 1989. Nutrition and feeding of fish. Van Nostrand Reinhold, New York, p. 260.

McGoogan, B. B. and D. M. Gatlin. 1999. Dietary manipulations affecting growth and nitrogenous waste production of red drum, Sciaenops ocellatus: I. Effects of dietary protein and energy levels. Aquaculture 178:333-348.

National Research Council (NRC). 1993. Nutrient requirements of fish. National Academy Press. Washington, DC, USA.

Page, J. W. and J. W. Andrews. 1973. Interaction of dietary levels of protein and energy on channel catfish (Ictalurus punctatus). J. Nutr. 103:1339-1346.

Pei, Z., S. Xie, W. Lei, X. Zhu and Y. Yang. 2004. Comparative study on the effect of dietary lipid level on growth and feed utilization for gibel carp (Carassius suratus gibelio) and Chinese longsnout catfish (Leiocassis longirostris Gunther). Aquac. Nutr. 10:209-216.

Satoh, S., W. E. Poe and R. P. Wilson. 1989. Effect of dietary n-3 fatty acids on weight gain and liver polar lipid fatty acid composition of fingerling channel catfish. J. Nutr. 119:23-28.

Statistics Korea. 2010. Fishery production survey. Retrieved Mar. 15, 2011, from http://fs.fips.go.kr.

Walton, M. J. and C. B. Cowey. 1982. Aspects of intermediary metabolism in fish. Comp. Biochem. Physiol. 73B:59-79.

Yoshimatsu, T., H. Imoto, M. Hayash, K. Toda and K. Yoshimura. 1997. Preliminary results in improving essential fatty acids enrichments of rotifer cultured in high diensity. Hydrobiologia 358:153-157. 